\title{
The use of natural tracers in the study of the unsaturated zone of a karst aquifer
}

\section{Uporaba naravnih sledil pri študiju nezasičene cone kraškega vodonosnika}

\author{
Branka TRČEK
}

Geološki zavod Slovenije, Dimičeva ul. 14, 1000 Ljubljana, Slovenija, e-mail:branka.trcek@geo-zs.si

Key words: karst aquifer, unsaturated zone, natural tracers, experimental field site Sinji vrh (SW Slovenia)

Ključne besede: kraški vodonosnik, nezasičena cona, naravna sledila, poskusno polje Sinji vrh (JZ Slovenija)

\begin{abstract}
The unsaturated zone of a karst aquifer was investigated in a catchment area of the Hubelj spring (SW Slovenia). The monitoring of flow and natural tracer transport was undertaken with the intention to study the recharge, storage and discharge processes of the karst aquifer, mixing processes, residence times and transport phenomena. The results point out the significance of effects of the fast preferential flow - epiflow. This flow is the main factor controlling contaminant transport towards the aquifer saturated zone.
\end{abstract}

\section{Kratka vsebina}

V zaledju izvira Hubelj (JZ Slovenija) so potekale raziskave nezasičene cona kraškega vodonosnika. Vzpostavil se je monitoring toka in prenosa naravnih sledil, katerega namen je bil študij procesov napajanja, uskladiščenja in praznjenja kraškega vodonosnika, procesov mešanja, zadrževalnih časov ter mehanizmov prenosa snovi. Rezultati so opozorili na vplive hitrega prednostnega toka - epitoka. Le-ta je glavni faktor za prenos in širjenje onesnaženja preko nezasičene cone do zasičene cone vodonosnika.

\section{Introduction}

Groundwater of karst aquifers is a very important source of drinking water supply in Slovenia. In order to protect the karst water from pollution it is necessary to investigate the behaviour of contaminants and thus to understand better natural factors that control its behaviour. However, the heterogeneity of karst aquifers makes it difficult to quantify and predict the movement of groundwater and contaminants through and/or between different aquifer zones. Concerning this the study of flow and solute transport mechanisms have been undertaken in a karst aquifer in the catchment area of the Hubelj spring (South-Western Slovenia) (Fig. 1) with the intension to answer several open questions connected with problems which result from the duality of the aquifer recharge, storage and discharge processes. This duality is reflected in the fast concentrated flow through the karst conduit network and the relatively slow diffuse flow from the low permeability rock blocks.

The research was focused on the study of mechanisms that cause flow and solute transport from an upper unsaturated zone 
that was investigated in an artificial tunnel 10 to $20 \mathrm{~m}$ below the surface (Fig. 1). This study based on natural tracers that are an important tool for investigating flow systems, mixing processes, residence time and connected storage properties of groundwater, water quality monitoring, dilution and biodegradation processes and transport phenomena.

\section{Description of the study area}

The catchment area of the karst spring Hubelj (Fig. 1) is estimated to $50-80 \mathrm{~km}^{2}$ (Trišič, 1997). This region belongs to the high karstic plateau Trnovski gozd with the mean altitude of $900 \mathrm{~m}$ a.s.l. The plateau consists of carbonate rocks that are covered by shallow soils $(10-50 \mathrm{~cm})$ of low water holding capacities (22-142 mm) and high infiltration rates (Ma ti či č, 1997). The average annual precipitation amount is $2450 \mathrm{~mm}$, while the average annual air temperature is $7-9{ }^{\circ} \mathrm{C}$,

The highly karstified carbonate, consisted mainly of the Jurassic limestone, is bounded by the Norian-Rhaetian dolomite in the north and by the Eocene flysch beds in the south and in the east (Fig. 1). The tectonic structure of the research region is complicated. The predominant tectonic elements are complex overthrusts cut by a dense system of subvertical faults (Janež et al., 1997). The Avče fault is the most important regional fault crossing the study area. Near the thrust lines carbonate rocks are finely crushed and ground and, consequently, less permeable.

The research was centered at three areas of the observed aquifer: the recharge area, the upper unsaturated zone and the discharge area. The latter was investigated in the Hubelj spring and the first two at the Experimental field site of Sinji vrh, which is located $600 \mathrm{~m}$ above the spring (Figs. 1,2).

Hubelj is one of the biggest Slovene karst springs. Its mean discharge is $3 \mathrm{~m}^{3} / \mathrm{s}$, the minimum one is $0.2 \mathrm{~m}^{3} / \mathrm{s}$, while the maximal one is $59 \mathrm{~m}^{3} / \mathrm{s}$ (Janež et al., 1997).

The upper unsaturated zone was investigated in an artificial tunnel which represented a natural laboratory for studies of chemical and stable isotopic composition of the seepage water, and with it the drainage system of the tunnel cover. The tunnel lies 5 to $25 \mathrm{~m}$ below the surface at $825 \mathrm{~m}$ mean altitude (Fig. 2). This area consists of the limestone of Lias-Dogger age (Čenčur Curk \& Veselič, 1999; Čenčur Curk, 2002; Trček, 2001). Since the Experimental field site of Sinji vrh belongs to a region of the Avče fault, the rock is fractured, broken and crushed near the fault lines.

\section{Methods and techniques}

Monitoring of flow and natural tracer transport was performed during the period from 1999 to 2000 . The saturated zone outflow was monitored in the Hubelj spring,

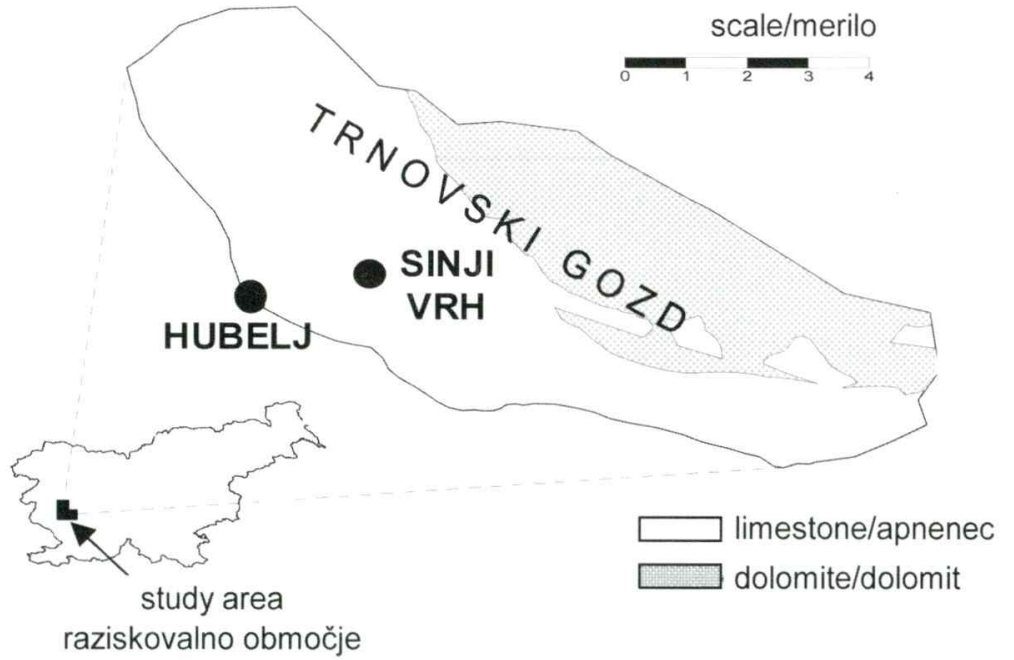

Figure 1. Study area. Slika 1. Raziskovalno območje. 


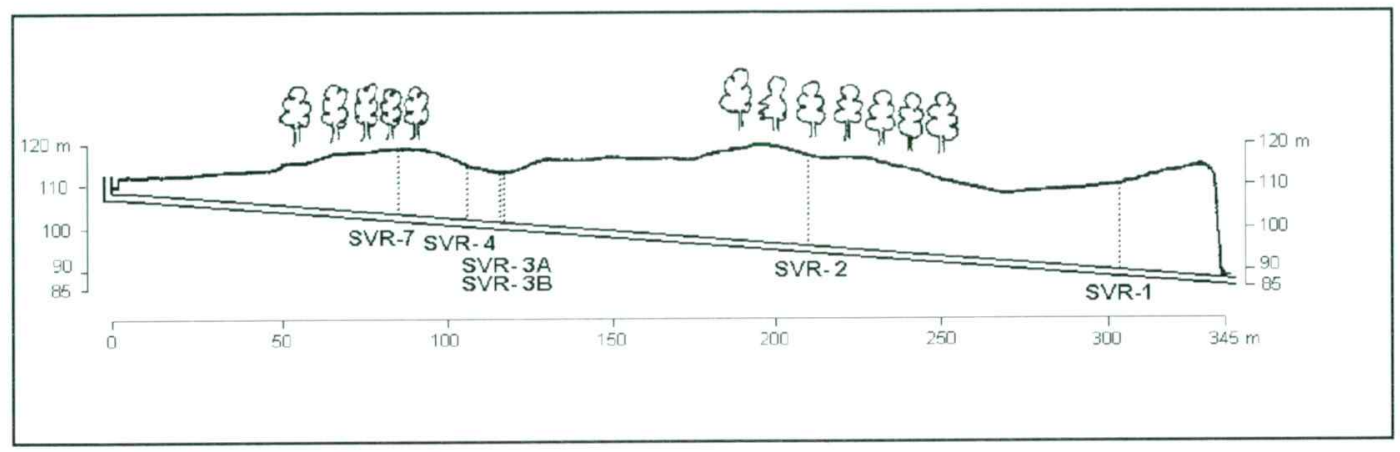

Figure 2. Longitudinal section of the artificial tunnel Sinji vrh with sampling points for isotopic and chemical analyses.

Slika 2. Vzdolžni prerez umetnega rova Sini vrh z vzorčevalnimi mesti za izotopske in kemijske analize vode.

while the precipitation and the upper unsaturated zone seepage water were monitored near the tunnel entrance and at six tunnel sampling points (SVR-1, SVR-2, SVR-3A, SVR-3B, SVR-4 and SVR-7) respectively (Fig. 2). Continuous measurement of water balance and of physico-chemical water parameters ( $\mathrm{pH}$ and electroconductivity) were carried out to obtain basic information on the study area. Furthermore, monthly water sampling for analysis of ${ }^{18} \mathrm{O},{ }^{13} \mathrm{C}$, dissolved organic carbon (DOC) and alkalinity composition was undertaken to obtain additional information about mixing processes and groundwater residence times.

It could be said that the chemical composition of karst groundwater is quite uncomplicated, seeing that bicarbonate, calcium and sometimes magnesium species prevail. The most important processes that affect the chemical and isotopic composition of the total inorganic carbon in groundwater are a) the dissolution of $\mathrm{CO}_{2}$ in the unsaturated zone and b) the dissolution of carbonate $\mathrm{mi}$ nerals in unsaturated and saturated zones. The partial pressure of $\mathrm{CO}_{2}$ is the main factor that controls these two processes.

Alkalinity is a conservative tracer, because changes of the carbonic acid concentration do not have influence on it. Alkalinity is defined as an excess of base cations over acid anions (Sigg et al., 1992). Thus, it is a measure for a system reaction. Lower the alkalinity value, lower is the dissolution of carbonate minerals in water, which results into lower bicarbonate ion concentration. On the other hand this reflects lower carbonic acid concentration as the consequence of lower partial pressure of soil $\mathrm{CO}_{2}$. It could be recapitulated that all these relationships express the seasonal variation of the discussed parameter.

Precipitation washes out of the soil also DOC, which originates from decomposition of the organic material in the upper soil horizon (Brooks et al., 1999). The DOC concentration depends besides on the soil properties also on the vegetation type, aquifer hydraulic characteristics and the unsaturated zone depth. The DOC concentration is usually between 10 and $100 \mathrm{mg} / \mathrm{l}$ in the soil, but it selectively decreases with the aquifer depth. Therefore, the values of the DOC concentration vary between 0.2 and $10 \mathrm{mg} / \mathrm{l}$ in groundwater, but they are frequently lower than 1-2 mg/l (Clark \& Fritz, 1997; Kendall \& MeDonell, 1998).

Significant quantities of DOC are washed out of the soil during the major precipitation events and snowmelt (Hongve, 1999). Hence it follows that the dissolved organic carbon is a potential tracer of the fast preferential flow in the karst aquifer. It was reported that a) DOC is a very important tool for the flow and solute transport studies of groundwater with residence time of at least one month (B a ti ot et al., 2000), and that b) high DOC concentrations in the aquifer deeper parts result from long residence time (Hongve, 1999).

The stable isotope of ${ }^{18} \mathrm{O}$ is an ideal conservative tracer under low temperature conditions (Clark \& Fritz, 1997). After the infiltration of precipitation only physical 
processes such as diffusion, dispersion, mixing and evaporation alter the groundwater ${ }^{18} \mathrm{O}$ isotopic composition $\left(\delta^{18} \mathrm{O}\right)$. Hence, the sampled water $\delta^{18} \mathrm{O}$ together with hydrometric data provides information on the movement and mixing of water masses on condition that the isotopic composition of each water masse significantly differs.

The seasonal variation of the precipitation $\delta^{18} \mathrm{O}$ represents an input signal that may be used for the groundwater dating. Namely, precipitation infiltrates into the soil and recharges the aquifer, where it is mixed with the pre-stored groundwater. This results in the input signal attenuation indicated in a lowering of the isotopic variation amplitude. Owing to different mixing and homogenisation stages, groundwater has different $\delta^{18} \mathrm{O}$ throughout the aquifer and with that different amplitude of the isotopic seasonal variation. These differences can be applied for the determination of groundwater residence time seeing that the longer the residence time, the lower is the amplitude of the groundwater isotopic seasonal variation.

Although the stable isotope of ${ }^{13} \mathrm{C}$ is not a conservative tracer, it can trace the carbon sources and the reactions for a multitude of inter-reacting organic and inorganic species. The groundwater ${ }^{13} \mathrm{C}$ composition $\left(\delta^{13} \mathrm{C}\right)$ gives information on the flow type and solute transport. It provides an insight into the water geochemical evolution, rock types in the flow paths surroundings and the recharge area conditions (Hoefs, 1997; Urbanc, 1993; Pezdič, 1999; Trček, 1997). It is well known that $\delta^{13} \mathrm{C}$ is about $0 \%$ in carbonate rocks, $-25 \%$ in the soil $\mathrm{CO}_{2}$ (similarly as in plants) and $-7 \%$ in the atmospheric $\mathrm{CO}_{2}$, respectively (Kendall \& Mc Donell, 1998; Pezdič, 1999).

$\delta^{13} \mathrm{C}$ varies like the alkalinity, but inverse proportionally. The higher values of $\delta^{13} \mathrm{C}$ usually occur during the winter. The deviations from general trends may result from hydrological events (e.g. storm events).
The characteristics of the isotopic composition of natural substances are described in numerous publications (e.g. Clark \& Fritz, 1997; Kendall \& McDonnell, 1998). Measurements of the stable isotopic composition of substances are conventionally reported in terms of a relative value d,

$$
\delta_{\mathrm{x}}(\%)=\left(\mathrm{R}_{\mathrm{x}} / \mathrm{R}_{\mathrm{st}}-1\right) \cdot 1000
$$

where $\mathrm{R}_{\mathrm{x}}$ is the isotope ratio (e.g. ${ }^{18} \mathrm{O} /{ }^{16} \mathrm{O}$ and ${ }^{13} \mathrm{C} /{ }^{12} \mathrm{C}$ ) in the substance $\mathrm{X}, \mathrm{R}_{\mathrm{st}}$ is the isotope ratio in the corresponding international standard substance, and d is expressed in parts per thousand.

\section{Laboratory measurements}

Most of water samples were analysed for $\mathrm{d}^{18} \mathrm{O}$ at the GSF-Institute of Groundwater Ecology in Germany (the first measurements were performed at the Josef Stefan Institute in Ljubljana), with a standard analytical error of $\pm 0.05 \%$.

The DOC composition of water samples was measured at the same institution. The standard analytical deviation was $\pm 0.05 \mathrm{mg} / \mathrm{l}$.

$\delta^{13} \mathrm{C}$ of water was analysed in the laboratory of the Jožef Stefan Institute in Ljubljana with the standard analytical error of \pm $0.15 \%$.

The alkalinity analyses were performed by me in the laboratory of the Geological Survey of Slovenia. The titration method was used according to instructions from the book Standard Methods for the Examination of Water and Wastewater (Greenberg et al.,1992).

\section{Statistical processing of data}

Data were statically analysed with boxplots, which are a very useful and concise graphical tool for summarising the distribution of data sets (Fig. 3). Boxplots visually illustrate a) the mean of the data (the median - the centre line of the box), b) the vari-

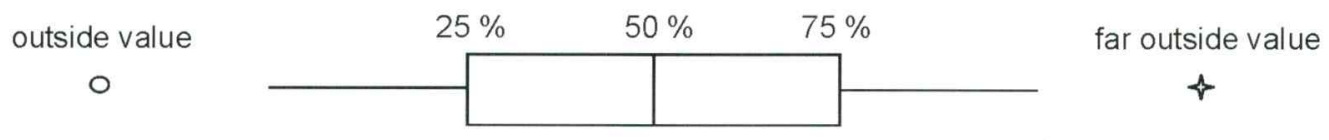

Figure 3. Description of the boxplot.

Slika 3. Opis škatlastega diagrama (o - oddaljena vrednost, - \& zelo oddaljena vrednost). 
ation or the spread (interquartile range - the box height), c) the skewness (quartile skew the relative size of box halves), and the presence or absence of unusual values (outside and far outside values) (Helsen \& Hirsch, 1992). They are even more useful for comparing these attributes among several data sets. In the case of normally distributed data, the outside values occur fewer than once in 100 times and far outside values fewer than once in 300000 times, respectively (Helsen \& Hirsch, 1992). If the occurrence of these values is more frequent than the expected, then this is an indication that data may not originate from a normal distribution.

\section{Results and discussion}

The most important results of the $\delta^{18} \mathrm{O}$ monitoring are the age estimations of the sampled groundwater (Trěek, 2002). Differences between the seasonal variation of $\delta^{18} \mathrm{O}$ in precipitation and in groundwater we- re taken into consideration. Because there is just the 2-year series of data for the study area precipitation, the data of the nearest compatible precipitation station (Ljubljana) were used. Polynomial trends (amplitudes and their phase shifts), linear trends and annual averages of sampled water $\delta^{18} \mathrm{O}$ were compared, which is summarised in Figure 4 . Because of the typical $\delta^{18} \mathrm{O}$ seasonal variation and its positive linear trend, the average residence time of the SVR-7, SVR-4, Hubelj and SVR-3A groundwater should be less than 5 years. On the other hand the average residence time of the SVR-3B, SVR1 and SVR-2 groundwater should be longer, owing to the untypical $\delta^{18} \mathrm{O}$ seasonal variation and its negative linear trend. The estimations of the groundwater average residence time for single sampling points are: 3 months for the SVR-7 groundwater, 9 months for the SVR-4 groundwater, 2-3 years for the Hubelj spring, 4-5 years for the SVR-3A groundwater, 5-6 years for the SVR-3B groundwater and at least 10 years for the SVR-1

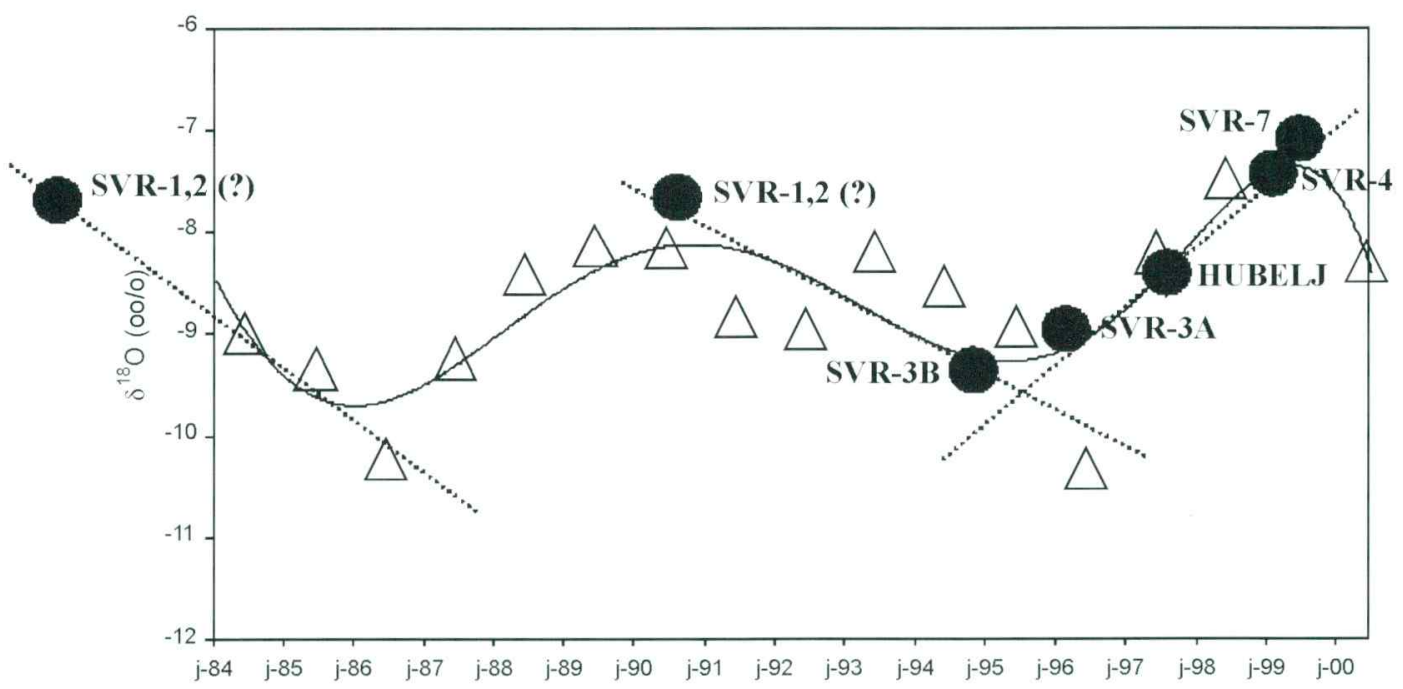

$\triangle \quad$ annual average of precipitation $\delta^{18} \mathrm{O}$ (1984-98 in Ljubljana, 2000 at Sinji vrh) / letno povprečje $\delta^{18} \mathrm{O}$ padavin (1984-98 v Ljubljani, 2000 na Sinjem vrhu) polynomial trend of precipitation $\delta^{18} \mathrm{O} /$ polinomni trend $\delta^{18} \mathrm{O}$ padavin

linear trend of precipitation $\delta^{18} \mathrm{O} /$ linearni trend $\delta^{18} \mathrm{O}$ padavin

average of sampled water $\delta^{18} \mathrm{O}$ in $2000 /$ povprečna $\delta^{18} \mathrm{O}$ vzorčene vode leta 2000

Figure 4. Trends of average annual $\delta^{18} \mathrm{O}$ of precipitation compared with average annual $\delta^{18} \mathrm{O}$ of groundwater sampled in the catchment area of the Hubelj spring.

Slika 4. Primerjava povprečne letne $\delta^{18} \mathrm{O}$ padavin in povprečne letne $\delta^{18} \mathrm{O}$ vzorčene podzemne vode $\mathrm{v}$ zaledju Hublja. 


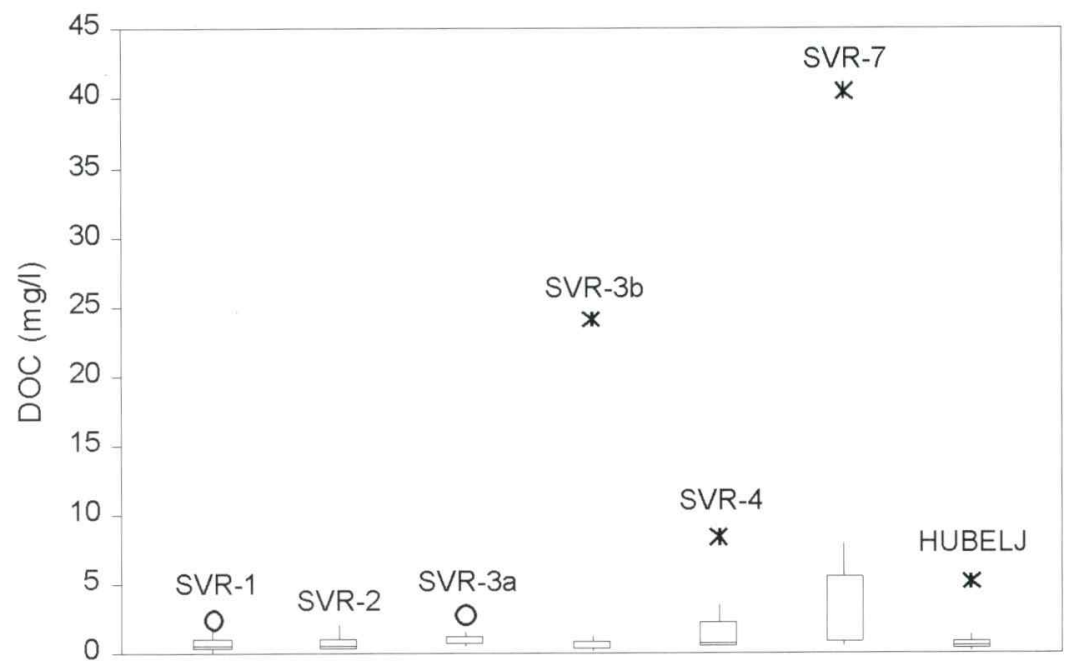

Figure 5. Boxplots of the dissolved organic carbon concentration of monthly water samples.

Slika 5. Škatlasti diagrami koncentracije raztopljenega organskega ogljika v mesečnih vzorcih vode. and SVR-2 groundwater (it can be one or more decades longer).

The major characteristics of the sampled water dissolved organic carbon (DOC) are presented in Figures 5 and 6. It could be noticed in Figure 5 that DOC values of SVR1, SVR-2, SVR-3A, SVR-3B and the Hubelj spring base flow waters (i.e. older groundwater) range similarly, from 0.1 to $2 \mathrm{mg} / \mathrm{l}$. Their means are $0.47,0.54,0.8,0.43$ and 0.59 $\mathrm{mg} / \mathrm{l}$, respectively. The one of the SVR-3A water is somewhat higher, which probably reflects the faster groundwater dynamics. On the other hand, the DOC ranges of the

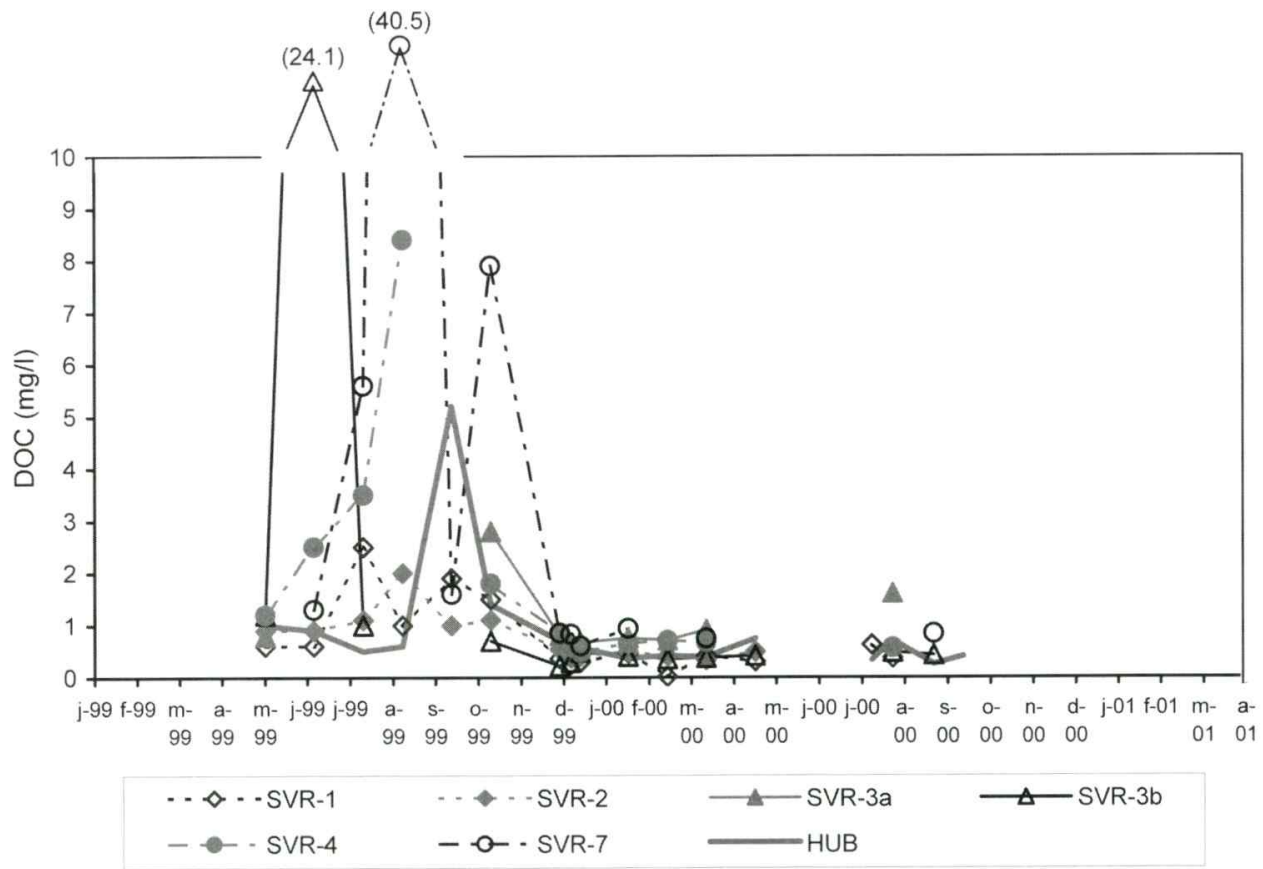

Figure 6. Time-trend of the dissolved organic carbon concentration of monthly water samples. Slika 6. Časovni prikaz koncentracije raztopljenega organskega ogljika v mesečnih vzorcih vode. 


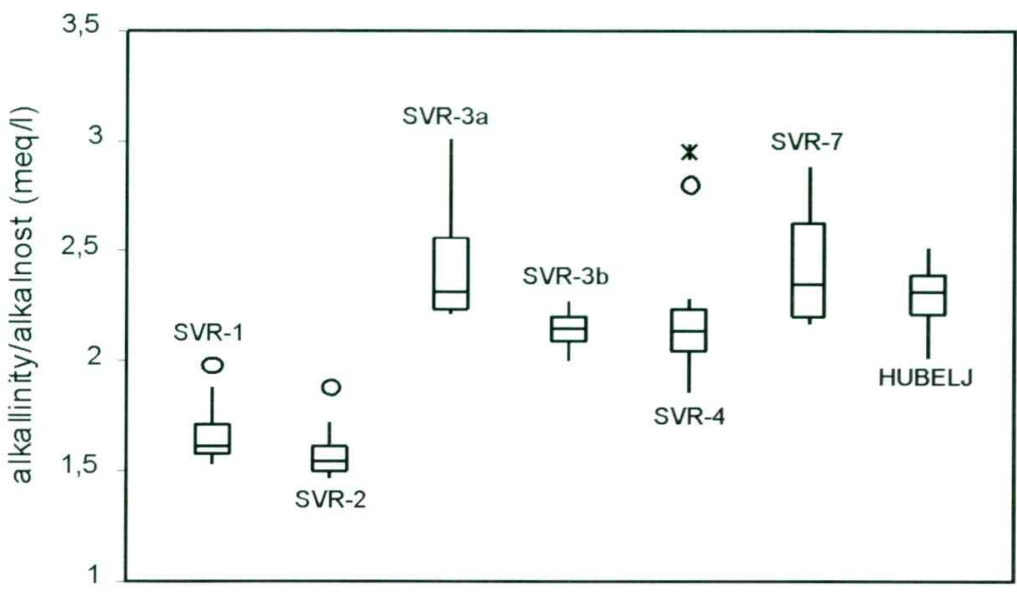

Figure 7. Boxplots of the alkalinity of monthly water samples.

Slika 7. Škatlasti diagrami alkalnosti v mesečnih vzorcih vode. younger groundwater of SVR-7 and SVR-4 are wider, particularly the former, which reflects the intensive groundwater dynamics. The corresponding means are somewhat higher with regard to the others, 0.78 and 0.94 $\mathrm{mg} / \mathrm{l}$ respectively, but yet similar to the one of the SVR-3A water.

The occurrence of the outlying and faroutlying values is distinctive for all sampled waters, except for the one of SVR-2 (Fig. 5). These values might result from the fast preferential flow. The flow effects are noticed in Figure 6, such as in the summer and autumn 1999 and in July 2000. During these periods the preferential flow had to wash out of the soil increased amounts of organic carbon compounds, which resulted in the increased DOC concentration of groundwater. The highest concentrations were measured in the SVR-7 water (Fig. 6). Hence, the recharge of he sampling point SVR-7 should be linked with the fastest drainage paths of all, which is in accordance with the shortest residence time of its water.

The boxplots in Figure 7 illustrate the statistical characteristics of the sampled water alkalinity. Waters of SVR-1 and SVR2 have by far the lowest mean alkalinity, 1.61 and $1.51 \mathrm{meq} / \mathrm{l}$ respectively, which reflect their lowest reactivity. Because of similarity of the alkalinity ranges and seasonal variations (Figs 7,8 ), the dynamics of these waters should be similar too. Owing to longer residence time, the water should slowly seep through the upper unsaturated zone and recharge these two sampling points.

In contrast to waters of the previous two sampling points, those of SVR-3A and SVR7 have the highest mean alkalinity values, 2.31 and $2.35 \mathrm{meq} / 1$ respectively, and the widest, and also similar, ranges of the alkalinity (Fig. 7). In this the highest reactivity as well as dynamics of all waters are reflected, which could be observed also in Figure 8. Therefore these two sampling points should be recharged through the fast drainage paths. Concerning that, it should be stressed that the average residence time of SVR-3A and SVR-7 waters differs considerably, which indicates that the fast flow does not comprise only the younger water.

Waters not mentioned yet are located between the above-quoted pairs in Figures 7 and 8 . Hence it follows that their reactivity and dynamics should be also in-between. Waters of SVR-4 and SVR-3B have similar alkalinity means, 2.15 and 2.13 meq/ 1 respectively, and ranges, but a different distribution of data. The Hubelj spring data range somewhat different from the previous two, but they are similarly distributed like those of the SVR-4 water. However, the mean value of the spring alkalinity, 2.31 $\mathrm{meq} / \mathrm{l}$, is the same as the one of the SVR-3A water.

At the end the attention should be given also to two pairs of waters, namely (a) the waters of SVR-7 and SVR-4, and (b) the waters of SVR-3A and SVR-3B. Waters of each pair have a similar average residence 


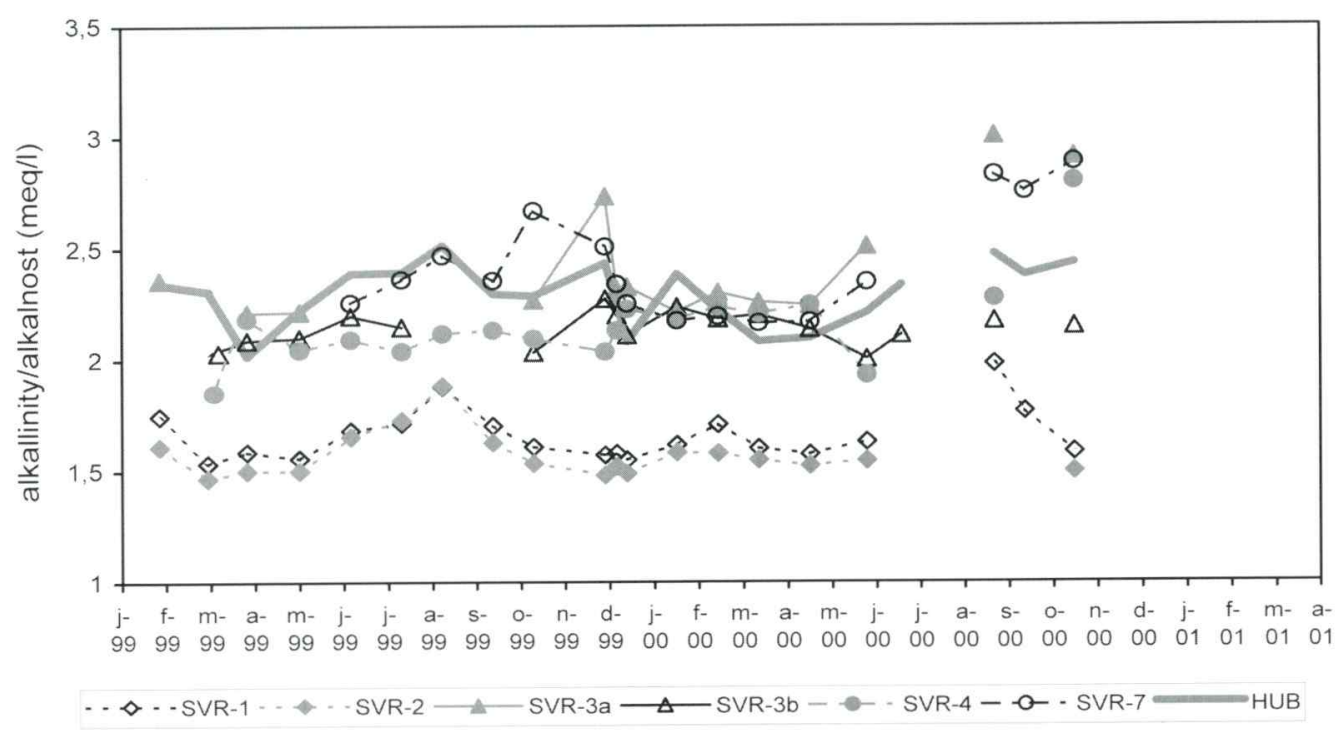

Figure 8. Time-trend of the alkalinity of monthly water samples.

Slika 8. Časovni prikaz alkalnosti v mesečnih vzorcih vode.

time, which differs for a definite shift. According to the interpretation of Figures 7 and 8 , the two sampling points of each and every one pair should have the same catchment area, but their recharge should depend on the different dynamics leading to shifts of their average residence time. The hydrodynamic conditions under which the sampling point SVR-7 and SVR-4 or SVR$3 \mathrm{~A}$ and SVR-3B were recharged by the water of the similar composition could be noticed in Figure 8.

The results of $\delta^{13} \mathrm{C}$ are illustrated in Figures 9 and $10 . \delta^{13} \mathrm{C}$ data of SVR-3A and SVR-7 waters with the highest dynamics range the least of all, and have the lowest means, 14.28 and $-13.5 \%$ respectively (Fig. 9). These mean values indicate the dissolution of carbonate minerals by carbonic acid, since they occur between $\delta^{13} \mathrm{C}$ of carbonate rocks and soil $\mathrm{CO}_{2}$ (Kendall \& McDonell, 1998).

On the other hand, the oldest waters of SVR-1 and SVR-2 with the slowest dynamics have the widest ranges of $\delta^{13} \mathrm{C}$ (Fig. 9). Their mean values are -8.32 and $-9.4 \%$ respectively, which is most probably the result of (a) isotopic exchange between the groundwater and the rock matrix, (b) degassing process, or (c) dissolution of carbonate rocks by stronger acids (Huneau \& Blavoux, 2000; Kendall \& McDonell, 1998).
In contrast to this is the explanation for the widest data ranges not so evident. With regard to the longest average residence time and the slow dynamics just the opposite would be expected - that $\delta^{3} \mathrm{C}$ of these waters would be the most homogeneous. Why this is not so?

Since the answer could not be found in the literature, I found my own explanation, which was discussed and approved by Professor Jože Pezdič from the Ljubljana University. It presumes that the sampling points SVR-1 and SVR-2 are recharged by the laminar flow from a low permeability rock matrix. At times of intensive hydrological events, this matrix could be influenced by a flow breakthrough containing some portions of the event and soil water. These breakthroughs might be the reason for larger deviations of some $\delta^{13} \mathrm{C}$ values from the relatively homogeneous $\delta^{13} \mathrm{C}$, which was verified by the analysis of Figure 10, and particularly by results of the short-term sampling during the storm event ( $\operatorname{Trček}, 2003$ ).

In spite of all that, the discussed effect is not characteristic for $\delta^{18} \mathrm{O}$ of SVR-1 and SVR2 waters, since the breakthrough water most probably does not differ much from the water previously stored in the rock matrix.

Remains the description of $\delta^{13} \mathrm{C}$ of SVR$3 \mathrm{~B}$ and SVR-4 waters and of the Hubelj 


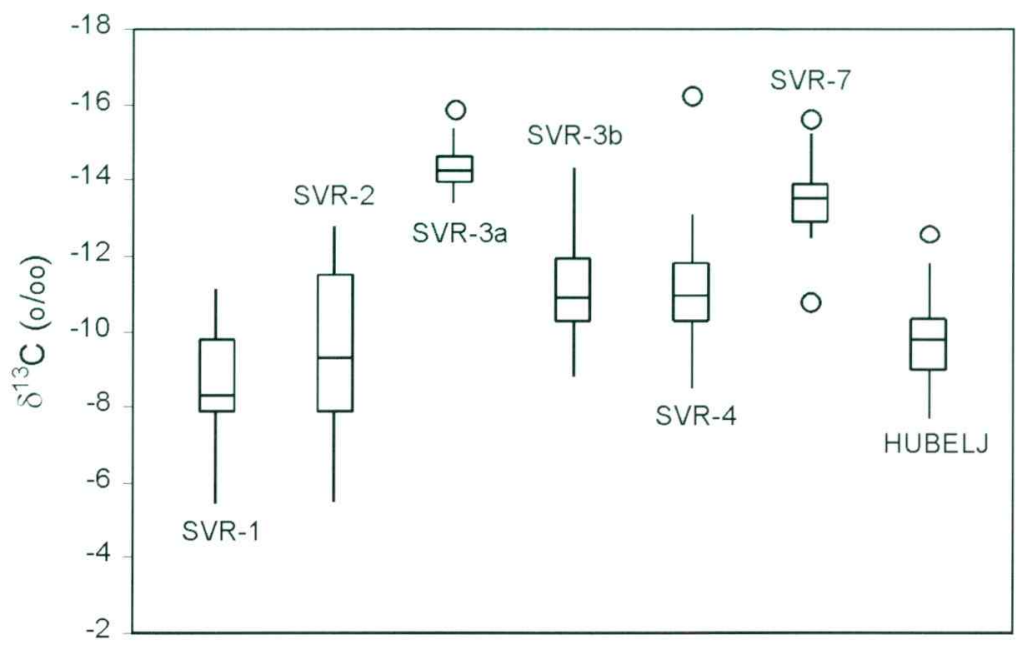

Figure 9. Boxplots of the $\delta^{13} \mathrm{C}$ of monthly water samples.

Slika 9. Škatlasti diagrami $\delta^{13} \mathrm{C} v$ mesečnih vzorcih vode. spring base flow. Since the ranges and the means of these data lie just between those previously discussed, the composition of these waters presumingly reflects the average geochemical and hydrodynamic conditions (Figs 9, 10).

The information of Table 1, which presents the water balance of the tunnel sampling points in 2000, additionally contributes to presented results: 1 ) the estimations of sampled water average residence time are indirectly verified by the sapling points volume, 2) it is evident that sampling points SVR-1 and SVR-2 are mostly recharged in the winter-spring period, 3) similar percentages of a) the SVR-3B, SVR-4 and SVR-7 water volume, and of $b$ ) the precipitation volume are noticed in each season, which reflects the piston effect, 4) the comparison between the water volume portions relating

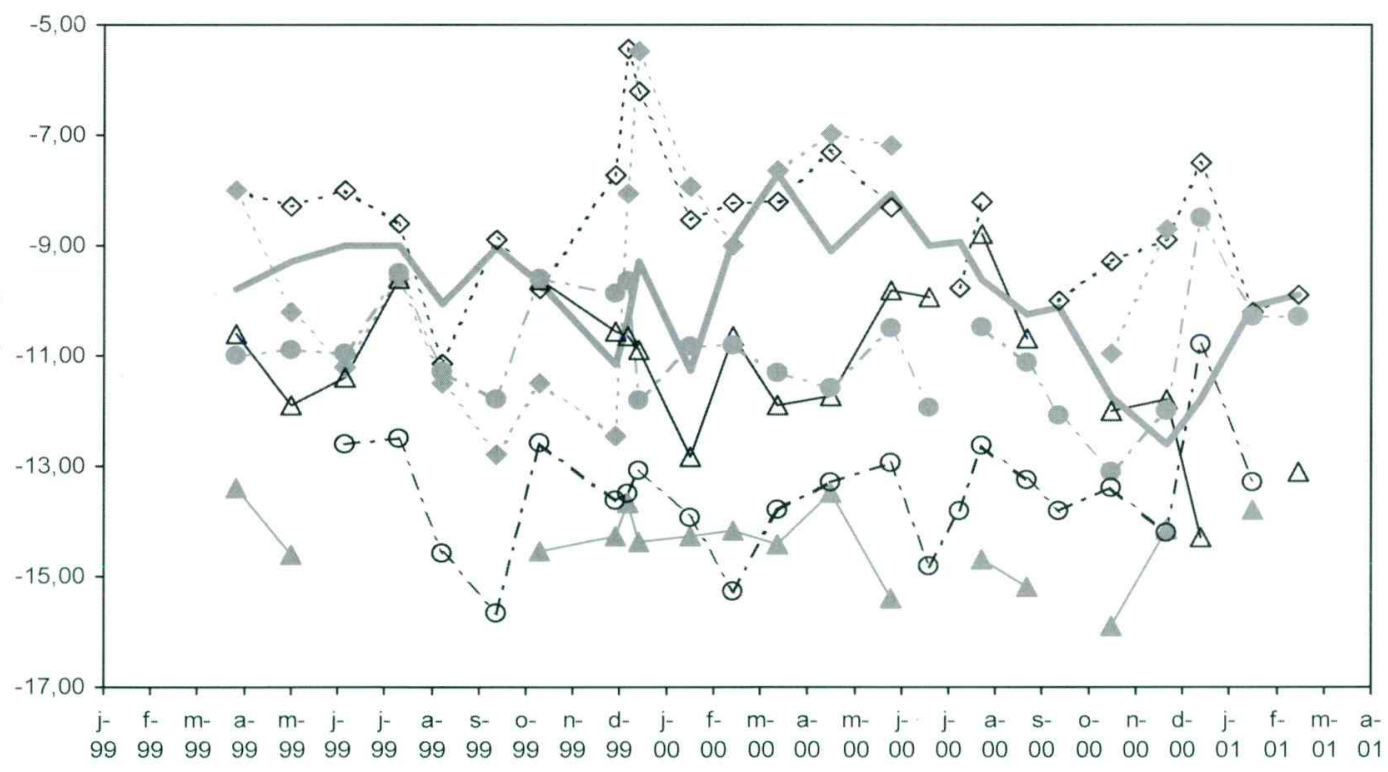

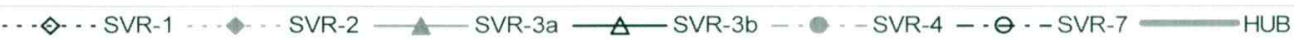

Figure 10. Time-trend of the $\delta^{13} \mathrm{C}$ of monthly water samples.

Slika 10. Časovni prikaz $\delta^{13} \mathrm{C} v$ mesečnih vzorcih vode. 
Table 1. Water balance of the tunnel sampling points in 2000 .

Tabela 1. Vodna bilanca vzorčenih vod v rovu v letu 2000.

\begin{tabular}{lccccccc}
\hline year/leto 2000 & SVR-1 & SVR-2 & SVR-3A & SVR-3B & SVR-4 & SVR-7 & $\begin{array}{c}\text { Precipitation/ } \\
\text { padavine (mm) }\end{array}$ \\
\hline $\begin{array}{l}\text { annual volume/ } \\
\text { letni volumen (1) }\end{array}$ & 4.7 & 5.1 & 10.5 & 13.5 & 10.1 & 10.7 & 2493.2 \\
$\begin{array}{l}\text { velocity (m/year)/ } \\
\text { hitrost (m/leto) }\end{array}$ & 0.47 & 0.51 & 1.05 & 1.35 & 1.01 & 1.07 & \\
$\begin{array}{l}\text { winter-spring vol. / } \\
\text { zimsko-pomlad. vol. (\%) }\end{array}$ & 76 & 66 & 21 & 34 & 31 & 30 & 27 \\
$\begin{array}{l}\text { summer vol./ } \\
\text { poletni vol. (\%) }\end{array}$ & 14 & 0 & 59 & 16 & 14 & 17 & 19 \\
$\begin{array}{l}\text { autumn-winter vol./ } \\
\text { jesensko-zimski vol. (\%) }\end{array}$ & 10 & 34 & 20 & 50 & 55 & 53 & 54 \\
$\begin{array}{l}\text { max./maks. vol. (\%) } \\
\text { Mar. }\end{array}$ & Jan. & Jul. & Nov. & Oct. & Oct. & Nov. \\
\hline
\end{tabular}

to the storm event points out a) the greatest dynamies of SVR-3A, which should most probably result from the epiflow, and reflects that $b$ ) the laminar flow had to recharge SVR-1 and SVR-3B, while c) SVR-4 and SVR-7 had to be partially recharged also by the faster flow.

It is presumed that the artificial tunnel near Sinji vrh penetrates the epikarst zone as well as the lower unsaturated zone, while the space between them belongs to the socalled transitional area.

The characteristics of waters of sampling points SVR-7 and SVR-4 indicate the epikarst zone. The water that has been previously stored in the aquifer higher areas should mostly recharge the two sampling points. Owing to the piston effect, this water should be discharged to the sampling points through the fast drainage paths.

The characteristics of waters of sampling points SVR-1 and SVR-2 demonstrate that the tunnel most probably penetrates the lower unsaturated zone in this area. The sampling points should be recharged by the laminar flow from the tiny fractured rock blocks.

The characteristics of waters of sampling points SVR-3A and SVR-3B indicate the transition area. Both sampling points should be recharged from the same catchment, only that the former should be recharged by the epiflow and the latter by the diffuse flow from the epikarst zone. It is presumed that the epiflow is linked to larger tectonic fractures that might be connected with a shaft.

\section{Conclusions}

It could be summarised that data of natural tracers monitoring provided a) an insight into the sampled water dynamics and reactivity and b) the estimations of sampled water average residence times. The significance of effects of the fast preferential flow-epiflow and of the duality of recharge processes was pointed out.

The results are in agreement with the epikarst hypothesis which presumes that an important part of the karst aquifer recharge rapidly arrives into the karst aquifer conduit network from the epikarst zone. The epikarst zone plays the role of a Faraday cage with respect to lower aquifer parts, resulting in the water concentration and storage (Kiraly et al., 1995). Epiflow is the main factor controlling contaminant transport towards the aquifer saturated zone.

The presented results could improve the karst aquifer vulnerability characterisation and thus contribute to the development of karst areas.

\section{Acknowledgement}

I would like to acknowledge Professor Miran Veselič and Professor Jože Pezdič of the University in Ljubljana who served as mentors for the Hydrogeology and Isotope Science respectively and Professor Klaus-Peter Seiler and Wilibald Stichler from the GSFInstitute of Groundwater Ecology (Germany) for chemical and isotopic analyses. 


\section{Uporaba naravnih sledil pri študiju nezasičene cone kraškega vodonosnika (povzetek)}

Kraški vodonosniki so pomemben vir kakovostne vode $v$ Sloveniji, zato jih je treba varovati pred onesnaženjem in prekomernim izkoriščanjem. Glede na to, postaja študij toka in prenosa snovi v kraškem vodonosniku vse pomembnejši. Bil je tudi predmet raziskav, ki so potekale $\mathrm{v}$ zaledju kraškega izvira Hubelj (sl.1). Pozornost je bila namenjena študiju mehanizmov, ki povzročijo tok in prenos snovi iz nezasičene cone vodonosnika.

V raziskavo so bila vključena opazovanja a) zasičene in b) nezasičene cone vodonosnika. Prva se je opazovala na izviru Hublja, ki predstavlja glavni iztok vode iz kraškega vodonosnika, druga pa na poskusnem polju Sinji vrh, okoli $600 \mathrm{~m}$ nad izvirom Hublja (sl. 1). Nezasičena cona vodonosnika se je proučevala $\mathrm{v}$ umetnem rovu, 5 do $25 \mathrm{~m}$ pod površjem (sl. 2).

Raziskovalna metodologija je temeljila na naravnih sledilih, vključujoč monitoring stabilnih izotopov $\left({ }^{18} \mathrm{O}\right.$ in $\left.{ }^{13} \mathrm{C}\right)$ in kemijskih parametrov (raztopljen organski ogljik DOC in alkalnost) v podzemni vodi, vzorčeni v rovu in na izviru Hublja, ter v padavinah, vzorčenih na poskusnem polju Sinji vrh. Monitoring toka in prenosa naravnih sledil je potekal v letih 1999 in 2000 z namenom, da se prouči procese napajanja, uskladiščenja in praznjenja kraškega vodonosnika, procese mešanja, zadrževalne čase podzemne vode ter mehanizme prenosa snovi.

Razlike med amplitudami sezonskega nihanja izotopske sestave kisika $\left(\delta^{18} \mathrm{O}\right) \mathrm{v}$ padavinah in $\mathrm{v}$ podzemni vodi so omogočile oceno povprečnega zadrževalnega časa vzorčene podzemne vode:

- okoli 3 mesece za vodo SVR-7,

- okoli 9 mesecev za vodo SVR-4,

- 2-3 leta za bazni tok Hublja,

- 4-5 let za vodo SVR-3A,

- 5-6 let za vodo SVR-3B,

- najmanj 10 let, lahko pa tudi eno ali več dekad daljši, za vodo SVR-1 in SVR-2 (sl. 4).

Sliki 5 in 6 prikazujeta glavne DOC v vzorčenih vodah. $\mathrm{Na}$ prvi sliki opazimo, da imajo vode SVR-1, SVR-2, SVR-3A, SVR-3B in baznega toka Hublja (starejše vode) podoben razpon vrednosti. Tudi njihove sred- nje vrednosti so podobne; nekoliko višjo ima le voda SVR-3A, kar verjetno odseva hitrejšo dinamiko podzemne vode. Po drugi strani sta razpona vrednosti parametra mlajših vod SVR-7 in SVR-4 precej širša, zlasti prve, kar odseva intenzivno dinamiko podzemne vode. Glede na druge, sta tudi srednji vrednosti teh vod ustrezno višji, vendar podobni, kot je tista vode SVR-3A.

Nastopanje oddaljenih in zelo oddaljenih vrednosti (sl. 3) je značilno za vse vzorčene vode, razen za vodo SVR-2 (sl. 5), kar je lahko posledica prednostnega toka, katerega vplive zasledimo na sliki 6 (očitni so npr. poleti in jeseni 1999). V teh obdobjih so morale padavine sprati večje količine organskih snovi iz tal, kar je povzročilo povišanje koncentracije DOC v podzemni vodi. Najvišje koncentracije so bile izmerjene $\mathrm{v}$ vodi SVR-7. Glede na to mora biti napajanje tega vzorčnega mesta vezano na najhitrejše drenažne poti izmed vse, kar je v skladu z oceno najkrajšega zadrževalnega časa vode SVR7.

Lastnosti alkalnosti in izotopske sestave ${ }^{13} \mathrm{C}\left(\delta^{13} \mathrm{C}\right)$ vzorčenih vod so prikazane na slikah 7 - 10. Podatki obeh parametrov nudijo podobne informacije. Srednje vrednosti in razponi parametrov vod SVR-1 in SVR-2 odsevajo najnižjo reaktivnost in podobno, glede na zadrževalni čas počasno, dinamiko podzemnih vod. V nasprotju s prejšnjimi pa odsevajo srednje vrednosti in razponi parametrov vod SVR-3A in SVR-7 najvišjo reaktivnost in najhitrejšo dinamiko podzemnih vod izmed vseh. Pri tem je treba poudariti, da se oceni povprečnega časa vod SVR-7 in SVR-3A precej razlikujeta med seboj, torej ni nujno, da je hiter tok povezan le z mlajšimi vodami. Vode SVR-4, SVR-3B in baznega toka Hublja nastopajo med zgoraj omenjenimi pari, zato verjetno odsevajo vmesne geokemične in hidrodinamične pogoje.

Namenimo pozornost še paroma vod s podobnimi zadrževalnimi časi: vodam a) SVR7 in SVR-4 ter b) SVR-3A in SVR-3B. Glede na interpretacijo vseh merjenih parametrov imajo najverjetneje vzorčna mesta vsakega posameznega para isto napajalno zaledje, razlikujejo pa se po dinamiki procesa napajanja, kar vodi do zamikov povprečnih zadrževalnih časov vod.

Sinteza vseh podatkov kaže na možnost obstoja epikraške cone v kraškem vodono- 
sniku zaledja Hublja. Predvideva se, da umetni rov pri Sinjem vrhu predira na začetku epikraško cono, na koncu spodnjo nezasičeno cono, vmes pa tako imenovano prehodno območje, kar podpirajo tudi informacije, ki jih nudi bilanca vzorčenih vod $\mathrm{v}$ tabeli 1 .

Lastnosti vod SVR-7 in SVR-4 odsevajo epikraško cono. Kot posledica batnega efekta, naj bi se drenirala voda v vzorěni mesti prek hitrih drenažnih poti. Lastnosti vode SVR-1 in SVR-2 odsevajo spodnjo nezasičeno cono vodonosnika. Vzorčni mesti najverjetneje napaja razpršen laminaren tok iz drobno razpokanih blokov kamnin. Lastnosti vod SVR-3A in SVR-3B odsevajo prehodno območje. Vzorčni mesti naj bi imeli enako napajalno območje, le da je napajanje SVR-3A v glavnem vezano na hitri prednostni tok - epitok, napajanje SVR-3B pa na razpršen laminarni tok iz epikraške cone.

Monitoringa toka in prenosa naravnih sledil je omogočili vpogled v starostno strukturo, reaktivnost in dinamiko vzorčenih vod ter opozoril na dvojnost procesov napajanja kraškega vodonosnika. Opozoril je tudi na epitok (hiter koncentriran tok po omrežju kraških kanalov, ki se drenira iz epikraške cone, vsebuje pa tudi vodo ponikalnic), ki je glavni faktor za prenos in širjenje onesnaženja preko nezasičene cone do zasičene cone kraškega vodonosnika.

Rezultati so torej v skladu s tako imenovano epikraško hipotezo, ki predpostavlja, da pomemben del napajanja kraškega vodonosnika izvira hitro in $\mathrm{v}$ koncentrirani obliki iz epikraške cone. Ta fenomen ima lahko pomembne posledice na transport onesnaževalcev in druge gospodarske probleme, česar ne smemo zanemariti pri varovanju kraških podzemnih vodnih virov.

\section{References}

Brooks, P.D., Mcknight, D.M. \& Benca1a, K.E. 1999: The relationship between soil heterotrophic activity, soil dissolved organic carbon (DOC) leachate, and catchment-scale DOC export in headwater catchments. - Water Resources Research, 35/6, 1895-1902.

Clark, I.D. \& Fritz, P. 1997: Environmental Isotopes in Hydrogeology. - Lewis Publishers, 311 pp., New York.

Čenčur Curk, B. \& Veselič, M. 1999: Laboratory and Experimental Study of Contaminant Transport in Fractured and Karstified Rock. - Rudarsko-metalurški zbornik, 46/3, 425-442, Ljubljana.
Čenčur Curk, B. 2002: Flow and solute transport in fractured and karstified rocks: $\mathrm{PhD}$ thesis. - University of Ljubljana, 253 pp., Ljubljana.

Greenberg, E. A., Clesceri, S.L. \& Eaton. D.A. 1992: Standard Methods for the Examination of Water and Wastewater, $18^{\text {th }}$ edition. - American Public Health Association, 2275, Washington

Helsel, D.R. \& Hirsch, R.M. 1992: Statistical Methods in Water Resources. - Elsevier, 522 pp., Amsterdam.

Hoefs, J. 1997: Stable Isotope Geochemistry, Fourth Completely Revised, Updated and Enlarged Edition. - Springer-Verlag, 168 pp., BerlinHeidelberg.

Hongve, D. 1999: Production of dissolved organic carbon in forested catchments. - Journal of Hydrology, 224, 91-99.

Huneau, F. \& Blavoux 2000: Isotopic hydrogeology within the Miocen basin of Carpentras-Valreas (southern France). In: Proceedings of the TraM'2000 Conference on Tracers and Modelling in Hydrogeology. - IAHS, 433-438, Liège.

Janež, J., Čar, J., Habič, P. \& Podobnik, R. 1997: Vodno bogastvo Visokega krasa. Ranljivost kraške podzemne vode Banjšic, Trnovskega gozda, Nanosa in Hrušice. Geologija d.o.o, 167 pp., Idrija.

Kendall, C. \& McDonel1, J.J. 1998: Isotope tracers in catchment hydrology. - Elsevier, 722 pp., Amsterdam.

Kiraly, L., Perrochet, P. \& Rossier, Y. 1995: Effect of the epikarst on the hydrograph of karst springs: A numerical approach. - Bulletin d'Hydrogéologie, 14, 199-220.

Pezdič, J. 1999: Isotopes and geochemical processes: University textbook. - University of Ljubljana, Faculty of natural sciences, Department of geology, 269 pp., Ljubljana.

Ma tiči č , B. 1997: Agricultural threats to pollution of water of Trnovsko-Banjška Planota. In: A. Kranjc (ed.), Karst hydrogeological investigations in south-western Slovenia. - Acta carsologica, 26/1, 102-113.

Sigg, L., Stumm, W. \& Behra, P. 1992: Chimie des Milieux Aquatiques. Chimie des Eaux Naturelles et des Interfaces dans l'Environnement. - Masson, 391 pp., Paris.

Trček, B. 1997: Carbon isotopic composition of groundwater from Trnovsko-banjška plateau: Master's thesis. - University of Ljubljana, 108 pp., Ljubljana.

Trček, B. 2001: Solute transport monitoring in the unsaturated zone of the karst aquifer by natural tracers: PhD thesis. - University of Ljubljana, 125 pp., Ljubljana.

Trček, B. 2002: Epikarst zone of a karst aquifer - its characteristics and importance in karst hydrogeology. - Geologija, 45/2, 573-578.

Trček, B. 2003: Epikarst zone and the karst aquifer behaviour, a case study of the Hubelj catchment, Slovenia. - Geological Survey of Slovenia, 100pp., Ljubljana.

Trišič, N. 1997: Hydrology. In: A. Kranjc (ed.), Karst hydrogeological investigations in south-western Slovenia. - Acta carsologica, 26/1, 19-30

Urbanc, J. 1993: Characteristics of the carbon and oxygen isotopic composition of waters from carbonate rocks: PhD thesis. - University of Ljubljana, 144 pp., Ljubljana. 